\title{
Facies Interpretation, Depositional Environment and Sequence Stratigraphy of the Sartakht Formation in the Bakhshi Section, Located in Kalmard Block, East-Central Iran
}

\author{
Bibi Haniyeh Emraninasab ${ }^{1}$, Mohammad Hossein Adabi2, Mahmoodreza Majidifard ${ }^{3}$, \\ Nader Kohansal Ghadimvand ${ }^{4}$ \\ ${ }^{1}$ Department of Geology, North Tehran Branch, Islamic Azad University, Tehran, Iran \\ ${ }^{2}$ Department of Geology, Faculty of Earth Sciences, Shahid Beheshti University, Tehran, Iran \\ ${ }^{3}$ Research Institute for Earth Sciences, Geological Survey of Iran, Tehran, Iran \\ ${ }^{4}$ Department of Geology, Islamic Azad University, North Tehran Branch, Tehran, Iran \\ Email: "Haniyeh Emraninasab@yahoo.com
}

Received 2 April 2016; accepted 27 May 2016; published 30 May 2016

Copyright (C) 2016 by authors and Scientific Research Publishing Inc.

This work is licensed under the Creative Commons Attribution International License (CC BY). http://creativecommons.org/licenses/by/4.0/

(c) (i) Open Access

\begin{abstract}
Permian rocks in Kalmard block are recognized with Khan Group, enjoying various characteristics in different outcrops. This group is made up of three informal formations, namely Chili, Sartakht and Hermez. Middle Permian deposits (Sartakht formation) are composed chiefly of sandstone and carbonate rocks. This formation is composed of $58.6 \mathrm{~m}$ sandstone and dolomitic limestone in the Bakhshi section. Lower Permian carbonate deposits (Chili formation) unconformably underlie this formation while lateritic paleosols of upper Permian (Hermez formation) are depicted overlying an erosional unconformity above this formation. According to lithologic and microscopic investigations, the deposits of Sartakht formation can be divided into 2 siliciclastic petrofacies and 12 carbonate microfacies. Field observations, along with microscopic examinations, have resulted in identifying tidal flat, lagoon, shoal and open marine environments in the rocks of the studied formation. Vertical changes of microfacies and depth variation curve point to the high thickness of the microfacies of lagoon and shoal environments and low thickness of the microfacies of tidal flat and open marine environments. The carbonate-siliciclastic sequence of Sartakht formation is made up of a third-order depositional sequence, separated from carbonate depositions of lower Permian (Chili formation) and lateritic paleosols of upper Permian by type 1 sequence boundary (SB1). Siliciclastic deposits include LST system tract, and carbonate microfacies involve TST and


HST system tracts, separated from each other by MFS. Sartakht formation rocks in Bakhshi section are deposited in a low-angle homoclinal ramp, mostly in the inner ramp, located in the south of Paleotethys Ocean. The depositional sequence identified in Sartakht formation points to the age of middle Permian, conforming to middle Absaroka II supersequence. The upper erosional boundary between Sartakht and Hermez formations conforms to the global-scale sea level fall.

\section{Keywords}

Middle Permian, Kalmard Block, Sartakht Formation, Depositional Environment, Sequence Stratigraphy

\section{Introduction}

Central Iran, shaped like a triangle and as one of the major, largest and most complex geological units in Iran, is located in the center of Iran. Structural model of this area consists of separate blocks, separated by deep faults, and thus enjoy distinct characteristics. Kalmard Block, enjoying a northeastern trend, is situated between Kalmard faults in the east and those of Naein in the west [1].

\section{Bakhshi Section Position}

This section is located in the southwest of Kalmard Caravanserai (at 1:250,000 scale) [2] and northeast of Robat-e-khan village in Kalmard zone (at 1:100,000 scale) [3] (eastern central Iran). It is formed by geographical coordinates of $33^{\circ} 25^{\prime} 59^{\prime \prime} \mathrm{N}$ and $56^{\circ} 13^{\prime} 56^{\prime \prime} \mathrm{E}$, and is located about 65 kilometers from Tabas-Yazd main road, accessible by a two-kilometer-dirt road (Figures 1-3).

\section{Methodology}

To determine the facies characteristics and conditions of depositional environment as well as the sequences in this section, the geological maps of Tabas (at 1:250,000 scale) [2] and Robatkhan (at 1:100,000 scale) [3] are employed and then the required data are collected though examining literature including textbooks, papers, reports, etc. Regarding field observations, the lithological characteristics of the sequence including gradation, various depositional structures, various fossils and parasequences stacking pattern are recorded, and major stratigraphic surfaces such as Maximum Flood Surface (MFS), Sequence Boundaries (SB) and Transgressive Surface (TS) are recognized. According to laboratory investigations, moreover, carbonate microscopic thin sections are used to reveal the characteristics of microscopic facies (namely, grain size and other textual features), diagenetic characteristics and microfossils. The petrofacies of siliciclastic rocks are identified by studying thin sections. Having collected data from thin sections, the depositional environment of this formation is interpreted and explained. Field and microscopic evidence is also used to discuss the sequence stratigraphy of the studied sequence. Next, parasequences stacking pattern, unconformity surfaces, system tracts and the status of the studied sequence stratigraphy among the global sequences are also determined. Adopting Dickson's 1965 method [4], Alizarin-redis used to stain the thin sections to identify the type of carbonate minerals (distinguishing calcite from dolomite). Folk classification scheme [5] is used to classify siliciclastic petrofacies, and Dunham (1962) classification system [6], refined by Emry \& Klovan in 1971 is employed to describe the composition of the carbonate microfacies [7]. Additionally, a comparison is made between vertical changes of microfacies and recent depositional environment using information gathered from Wilson, 1975; Carozzi, 1989; Tucker \& Wright, 1990; Flügel, 2010 [8]-[11]. Having studied various methods in sequence stratigraphy studies, the depositional sequence model devised by Posamentier (1988) is used [12]. Regarding this model, "Sequence Stratigraphy" involves the study of rock relationships within the chronostratigraphic framework of a sequence, which in turn is acyclic succession of rocks composed of genetically related units of strata [12]. Finally, all information and data are combined, interpreted and explained.

\section{Stratigraphy}

Middle Permian deposits (Kubergandian-Murgabian-Midian stages), composed of mudstone, limestone and 


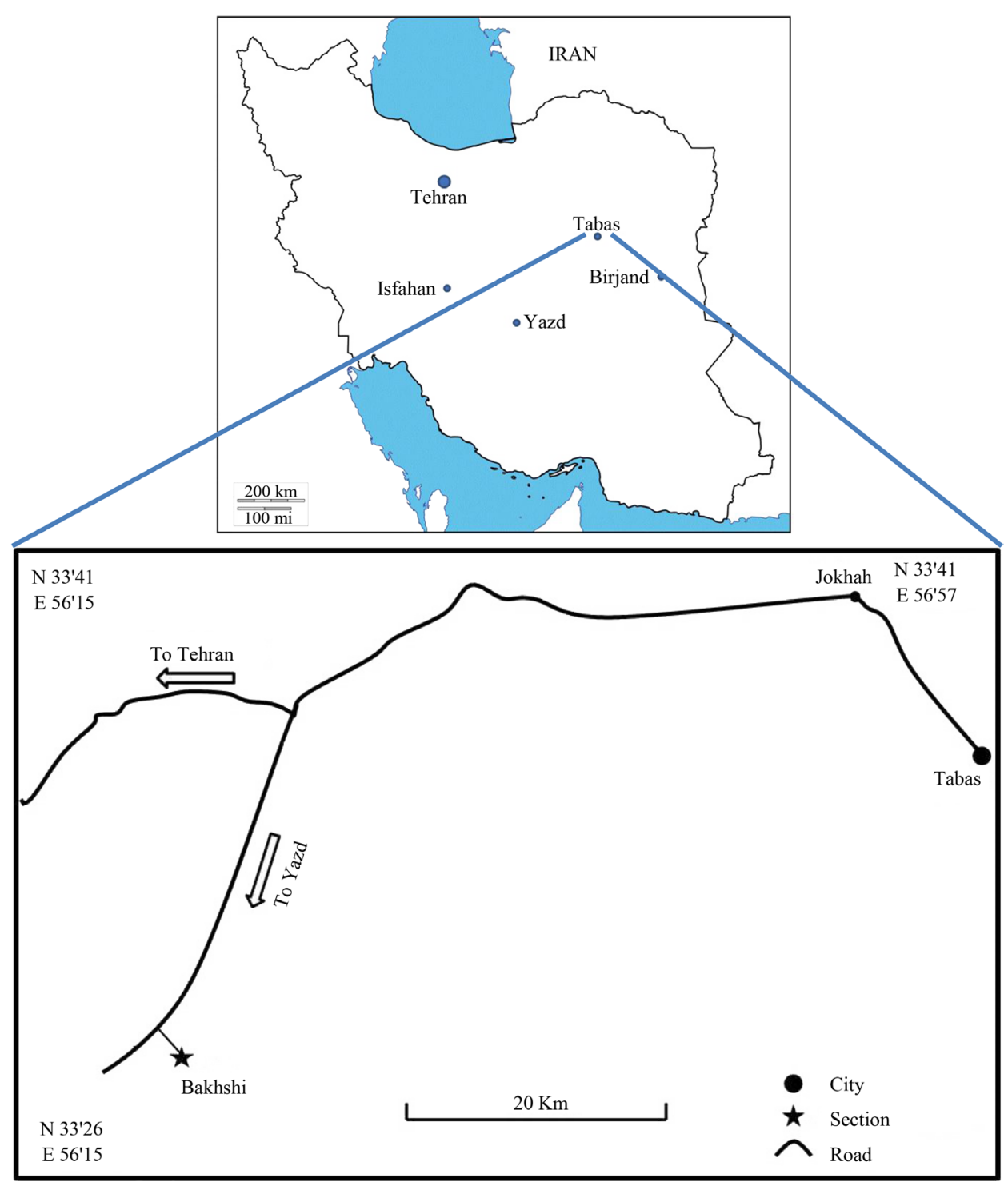

Figure 1. Geographical position and access way to Sartakht formation in Bakhshi section.

dolomitic limestone, are recognized in Kalmard block or Sartakht informal formation. One of the most comprehensive outcrops of Sartakht formation is located in Bakhshi section, in which deposits of Sartakht formation rocks have StrikeN42 E, Dip 80 NW and $58.6 \mathrm{~m}$ thickness. The lithology of Sartakht formation in Bakhshisection is composed chiefly of mudstone and dolomitic limestone, and, based on morphologic and lithologic characteristics, can be divided into four units including: thin-to-medium, red oxidized (lateritic) mudstone with 30 $\mathrm{m}$ thickness (unit 1), which has unconformably overlain the medium, yellow dolomitic limestone of Chili formation (lower Permian), medium mudstone with $8 \mathrm{~m}$ thickness (unit 2), medium, grey, horizontally stratified dolomitic limestone interbedded withthin-to-medium, red mudstone with 3 m thickness (unit 3) and thin-to-medium, light grey, horizontally stratified dolomitic limestone, interbedded with abundance of crinoid in the upper layers with $17.60 \mathrm{~m}$ thickness (unit 4). The unit unconformably underlies thin-to-medium, dark red, lateritic paleosols of Hermez formation (upper Permian).

\section{Facies Interpretation and Depositional Environment of Sartakht Formation in Bakhshi Section}

Lithologic and microscopic studies reveal that this sequence consists of two siliciclastic petrofacies and twelve 


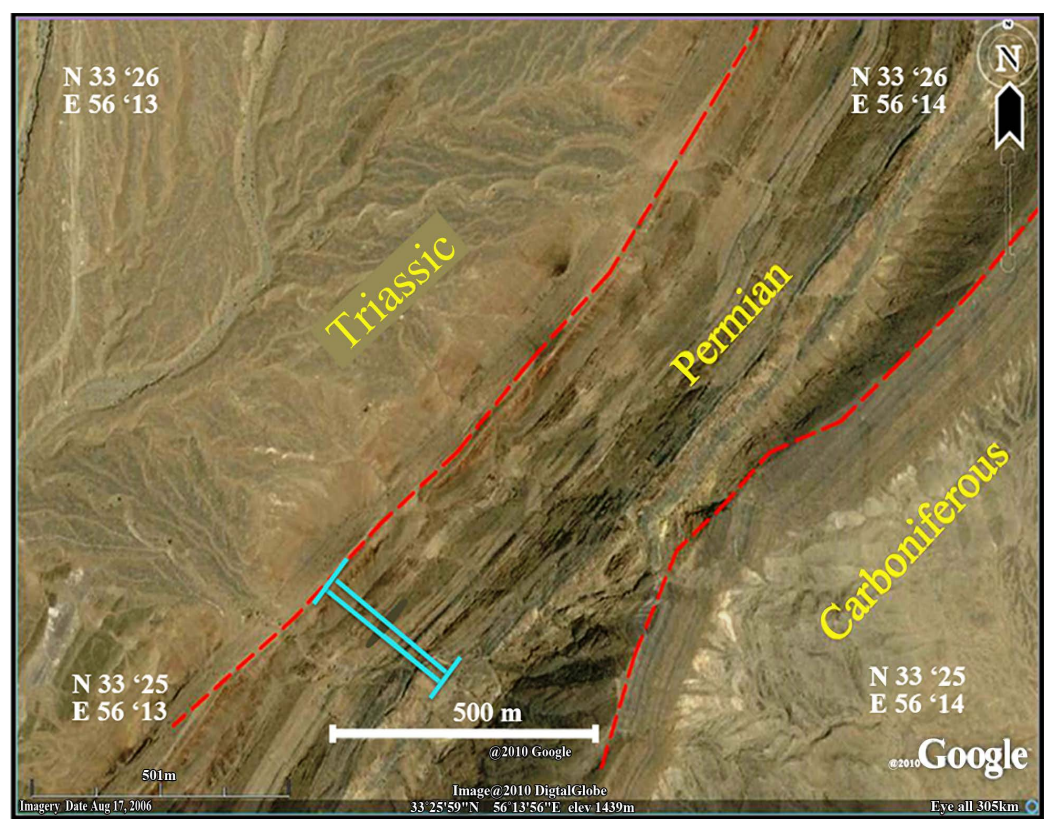

Figure 2. Satellite image of Sartakht formation in Bakhshi section, separation of sediments age based on Tabas map (at 1:250,000 scale) (Aghanabati, 1977).

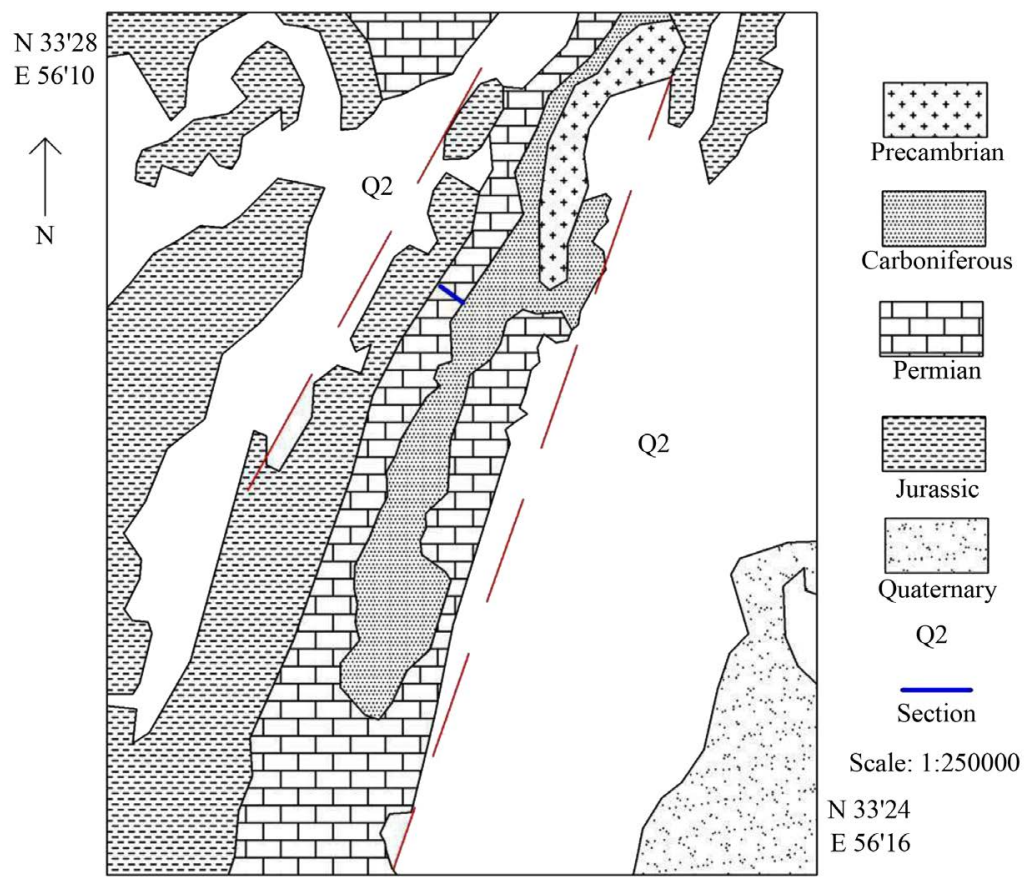

Figure 3. Geological map of Sartakht formation in Bakhshi section (Aghanabati, 1977).

carbonate microfacies. These siliciclastic petrofacies and carbonate microfacies of Sartakht formation are deposited on four facies belts including Tidal flat environment (A), Lagoon environment (B), Shoal environment (C) and Open marine environment (D). These facies belts, facing sea from the coast, include:

\subsection{Facies Belt}

A: Tidal flat environment 
This facies belt includes two petrofacies and two microfacies. $A_{1}$ and $A_{2}$ are siliciclastic petrofacies while $A_{3}$ and $\mathrm{A}_{4}$ are carbonate microfacies. These petrofacies and microfacies are deposited in the supertidal and intertidal subenvironments, described as follow:

$\mathrm{A}_{1}$ : Oxidized Sublitharenite petrofacies

This petrofacies involves $70 \%$ poorly sorted and rounded quartz and $20 \%$ rock fragments. Presence of quartz and rock fragments indicates that this facies is deposited not far from the entry point of siliciclastic materials. The oxidation of this facies implies its shallowness while being deposited. The average size of grains is $0.3 \mathrm{~mm}$ (Figure 4(a)).

\section{$\mathrm{A}_{2}$ : Quartzarenite petrofacies}

This facies is composed of $95 \%$ well sorted and semi-rounded, mature quartz grains in $0.2 \mathrm{~mm}$ size. This facies contains Quartzarenite petrofacies (Figure 4(b)).

$\mathrm{A}_{3}$ : Fenestral Sandy Bioclast Wackestone microfacies

This microfacies consists of microcrystalline lime mud, Bird's-eye and fenestral fabric pores, skeletal fragments and limited number of quartz particles (Figure 5(a)).

$\mathrm{A}_{4}$ : Dolomitized Fenestral Mudstone microfacies

This microfacies lacks allochem, yet involves a dolomitized fenestral or bird's-eye mudstone, interbedded ina limemud matrix (Figure 5(b)).

\section{Interpretation}

Living beings are rarely seen in the tidal flat environment, generally divided into supratidal and intertidal subenvironments. Petrofacies $A_{1}$ is an oxidized sublitharenite petrofacies, formed in the supratidal subenvironment and warm and humid climate as a result of intense chemical weathering [13] [14]. Petrofacies $A_{2}$, relating to lower intertidal, is a sign of relatively high energy in this subenvironment. Shallow water in this subenvironment accounts for the high percentage of quartz in this facies, having the ground for penetration of siliciclastic particles to this facies. Siliciclastic deposits can be found near hear [8] [11] [15]. On the other hand, the presence of iron oxide accounts for high amount of dissolved oxygen, which in turn confirms the shallowness of this subenvironment [8] [16]. Moreover, mature quartzarenite petrofacies confirms the high tidal flow regimes [17].

Microfacies of this group are recognized with abundant limemud. Bird's-eye or fenestral pores within the carbonate microfacies suggest deposition in tidal environment [18]. Fenestral fabric is formed as a result of losing water or burrowing activities of earthworms, and appropriately expanded within microfacies $A_{3}$ and $A_{4}$ [19] [20]. Microfacies $A_{3}$ consists of a limited amount of windblown, very fine-grained to silt, poorly sorted quartz. Lack of biological variation in microfacies $\mathrm{A}_{4}$ points to the lack of appropriate ecological conditions for marine life [21]-[23].

\subsection{Facies Belt}

\section{B: lagoon environment}
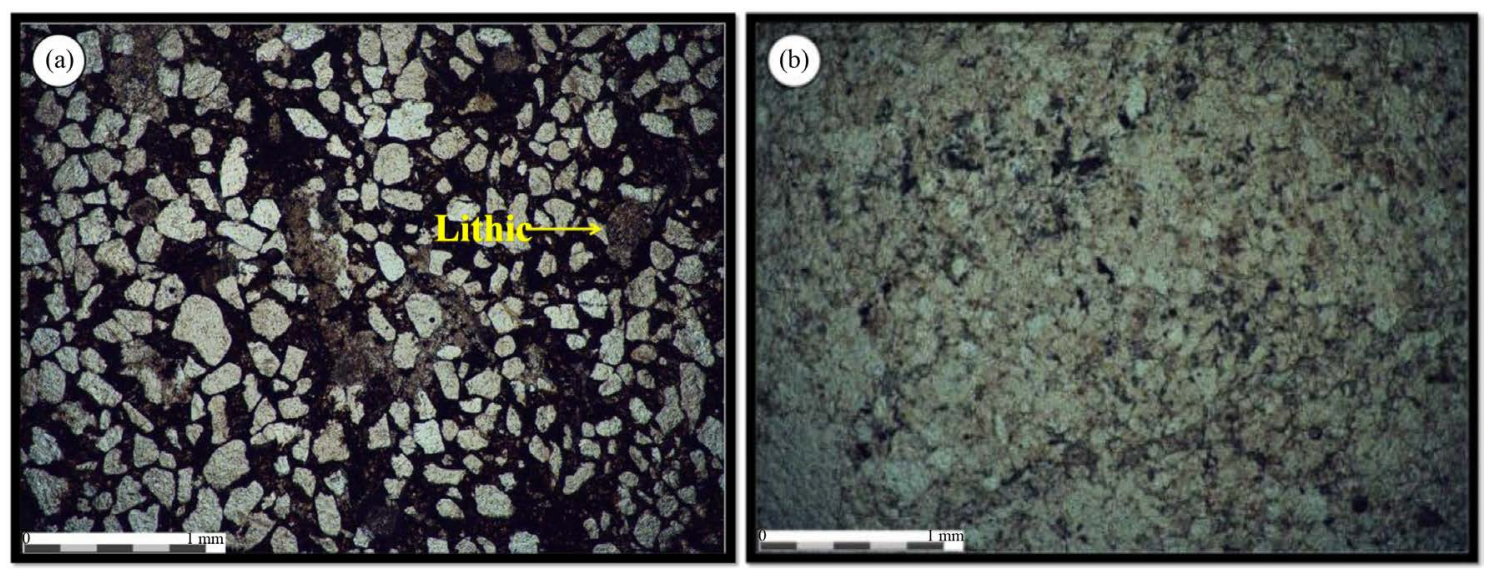

Figure 4. Siliciclastic petrofacies of tidal flat environment in Sartakht formation, Bakhshi section (a) Oxidized Sublitearenite; (b) Quartzarenite. $1 \mathrm{~mm}$ scale. 
This facies belt is composed of four microfacies as follow:

$\mathrm{B}_{1}$ : Sandy Dasycladacea Wackestone microfacies

This microfacies is made up of 35\% $2 \mathrm{~mm}$-sized fragments of dasycladacea algae and $30 \% 0.3 \mathrm{~mm}$-sized, poorly sorted and rounded quartz, located in a micriticmatrix (Figure 6(a)).

$\mathrm{B}_{2}$ : Dolomitized Sandy Bioclast Dasycladacea Crinoid Packstone microfacies

This microfacies consists of $20 \%$ crinoid with $1-2.5 \mathrm{~mm}$ in size, $10 \%$ sparite dasycladacea algae with $1 \mathrm{~mm}$
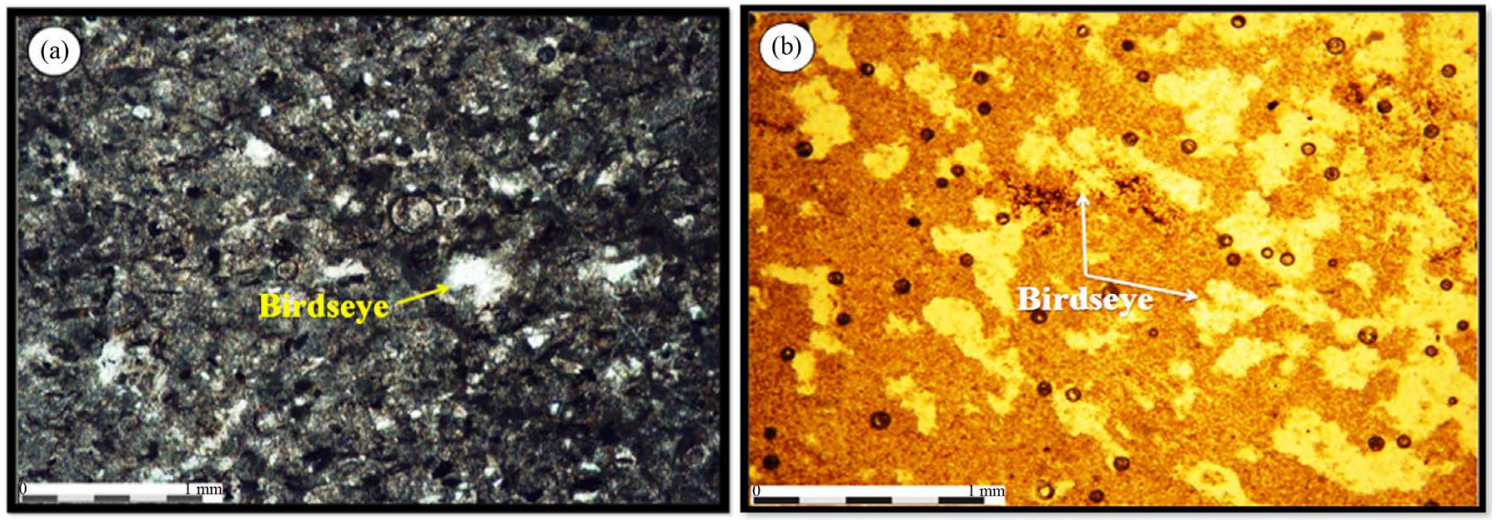

Figure 5. Siliciclastic petrofacies of tidal flat environment in Sartakht formation, Bakhshi section: (a) Fenestral Sandy Bioclast Wackestone; (b) Dolomitized Fenestral Mudstone. $1 \mathrm{~mm}$ scale.
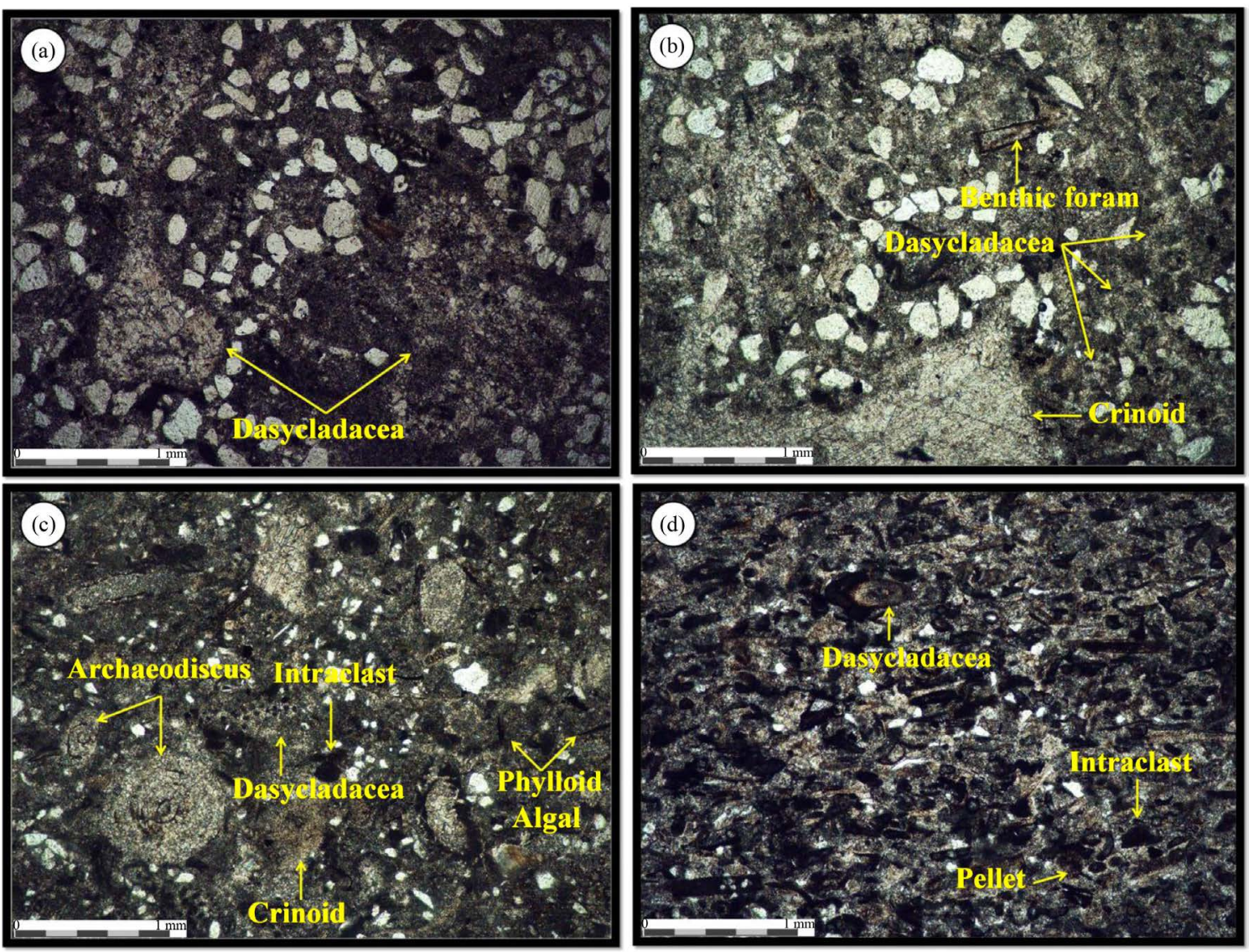

Figure 6. Lagoon carbonate microfacies of Sartakht formation in Bakhshi section: (a) Sandy Dasycladacea Wackestone; (b) Dolomitized Sandy Bioclast Dasycladacea Crinoid Packstone; (c) Bioturbated Dolomitized Sandy Intraclast Algal Bioclast Packstone; (d) Sandy Intraclast Algal Packstone. $1 \mathrm{~mm}$ scale. 
in size, less than $5 \%$ benthic foraminifera with $0.2 \mathrm{~mm}$ in size and $10 \%$ poorly sorted and rounded quartz with $0.3 \mathrm{~mm}$ in size, all of which are located in a micritic matrix. It is noteworthy that dolomitization also occurs in this microfacies (Figure 6(b)).

$\mathrm{B}_{3}$ : Bioturbated Dolomitized Sandy Intraclast Algal Bioclast Packstone

This microfacies consists of 5\% - 10\% archaeodiscus benthic Foraminifera with $0.8 \mathrm{~mm}$ in size, less than 5\% crinoid fragments with $0.5 \mathrm{~mm}$ in size, $5 \%$ dasycladacea and $2 \%$ phylloid algae, $5 \%$ intraclast with $0.2 \mathrm{~mm}$ in size and $5 \%$ poorly sorted and rounded quartz, all of which are located in a micritic matrix. This microfacies undergoes dolomitization processes. Additionally, evidence of bioturbation is also observed in this microfacies (Figure 6(c)).

$\mathrm{B}_{4}$ : Sandy Intraclast Algal Packstone

This microfacies includes $5 \%$ phylloid algae, $5 \%$ rounded intraclasts with $0.2 \mathrm{~mm}$ in size, less than $5 \%$ fragments of pelecypoda with $0.3 \mathrm{~mm}$ in size, $2 \% 0.1 \mathrm{~mm}$-sized pellet and less than $5 \%$ poorly sorted and rounded quartz, located in a micriticmatrix (Figure 6(d)).

\section{Interpretation}

Microfacies of this facies belt share such characteristics as presence of non-skeletal grains including pellet and lagoonal bioclasts such as benthic foraminifera, pelecypoda and green algae, capable of surviving in restricted and semi-restricted conditions [24]. The first common characteristics among microfacies of restricted lagoon environment is the presence of tranquility in their formation environment, and the second one is the high level of salinity in the depositional environment of the sediments of this group [23]. The distinctive feature of the microfacies of this group is due to the fabric type and grain size. Green algae and small foraminifera are observed in microfacies $B_{1}$ and $B_{2}$ in the euphotic zone, where the water is shallow while nutrients are abundant [23] [25]-[27]. High amount of quarzs grains in microfacies $B_{1}$ indicates that this microfacies belongs to shallow lagoon environment [23]. The presence of stenohalins such as crinoids in microfacies $B_{2}$ confirms the relation between lagoon and open marine. The semi-restricted lagoon environment experiences good water circulation, together with normal salinity and oxygen level [28]. Bioturbation is amongst the other characteristics of microfacies $B_{3}$, resulted from the activity of infauna and points to the deposition of this microfacies in a relatively calm environment with restricted water circulation and below the wave effect line. These microfacies are formed in shallower parts of lagoon under the low ambient conditions [10] [11]. Lagoon elements including pelecypoda, along with the presence of non-skeletal elements such as pellet and intraclast inmicrofacies $\mathrm{B}_{4}$ indicate the deposition of this microfacies in lagoon environment [10] [11]. Quarts grains (in sand size) in the microfacies of this group suggest the shallowness of this environment and its proximity to tidal flat environment.

\subsection{Facies Belt}

\section{C: Shoal environment}

This facies belt consists of five microfacies as follow:

$\mathrm{C}_{1}$ : Dolomitized Sandy Brachiopod Algal Crinoid Grainstone microfacies

This microfacies contains $20 \%$ crinoid with $0.5 \mathrm{~mm}$ in size, $15 \%$ tubiphytes algae with more than $1 \mathrm{~mm}$ in size, about $5 \%$ brachiopod fragments with $0.8 \mathrm{~mm}$ in size and $15 \%$ medium, poorly sorted and rounded quartz with $0.4 \mathrm{~mm}$ in size, situated in an area covered by sparry calcite cement. Also, this microfacies has been influenced by dolomitization process (Figure 7(a)).

$\mathrm{C}_{2}$ : Sandy Algal Intraclast Pelecypod Crinoid Grainstone

This microfacie sconsists of $15 \%$ crinoid with $1 \mathrm{~mm}$ in size, $10 \%$ pelecypoda fragments with $0.8 \mathrm{~mm}$ in size, $10 \%$ intraclast with $0.3 \mathrm{~mm}$ in size, $5 \%$ Phylloid algae with $0.5 \mathrm{~mm}$ in size and $5 \%$ poorly sorted and rounded quartz with $0.1-4 \mathrm{~mm}$ in size, situated in an area covered by sparry calcite cement. Also, this microfacies has been influenced by dolomitization process (Figure 7(b)).

$\mathrm{C}_{3}$ : Bioclast Bryozoan Grainstone microfacies

The most important allochem of this microfacies is $70 \% 5 \mathrm{~mm}$-sized bryozoan, located in asparry calcite cement matrix. This microfacies includes a little amount of skeletal fragments and phylloid algae as well (Figure 7(c)).

\section{$\mathrm{C}_{4}$ : Brachiopod Crinoid Grainstone}

This microfacies is composed of $20 \%$ crinoids with $0.8 \mathrm{~mm}$ in size and $15 \%$ brachiopod with $3 \mathrm{~mm}$ in size, 

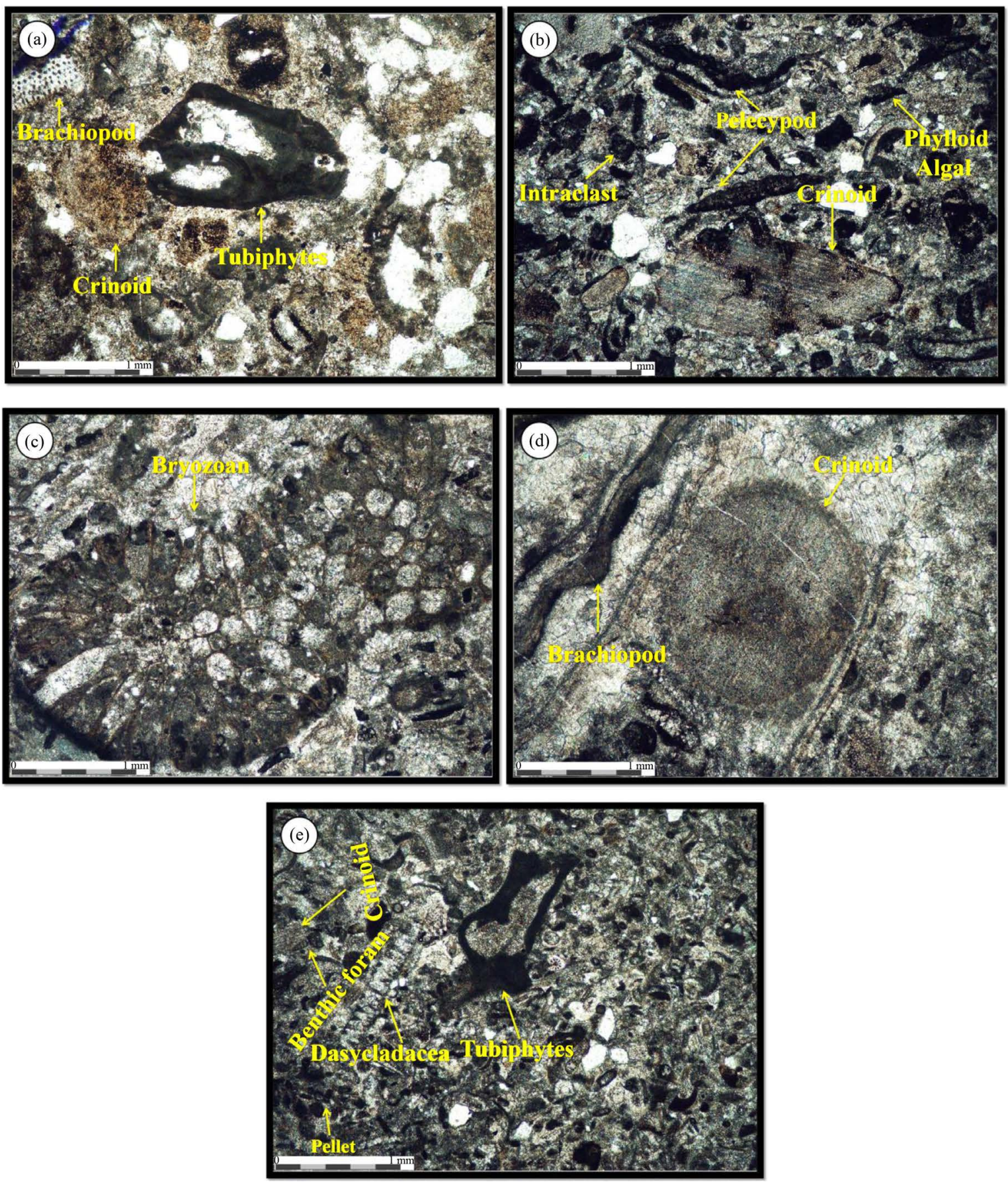

Figure 7. Carbonate microfacies of Shoal environment of Sartakht formation in Bakhshi section: (a) Dolomitized SandyBrachiopod Algal Crinoid Grainstone; (b) Sandy Algal Intraclast Pelecypod Crinoid Grainstone; (c) Bioclast Bryozoan Grainstone; (d) Brachiopod Crinoid Grainstone; (e) Sandy Bioclast Algal Packstone/Grainstone. 1 mm scale.

placed in a sparry calcite cement matrix (Figure 7(d)).

$\mathrm{C}_{5}$ : Sandy Bioclast Algal Packstone/Grainstone microfacies

This microfacies is made up of $10 \% 1.5 \mathrm{~mm}$-sized phylloid, dasycladacea, tubiphytes algae, $5 \%$ crinoid with $0.3 \mathrm{~mm}$ in size, $2 \%$ benthic foraminifera with $0.2 \mathrm{~mm}$ in size, $5 \%$ tiny fragments of pelecypoda and brachiopod with $0.2 \mathrm{~mm}$ in size, $3 \%$ pellet with $0.125 \mathrm{~mm}$ in size and $5 \%$ poorly sorted and rounded quartz, laid in a microspar matrix (Figure 7(e)). 


\section{Interpretation}

This facies belt is formed in shoal environment and below the wave effect due to the presence of skeletal fragments such as crinoid, bryozoan and brachiopod and non-skeletal fragments like intraclast as well as lack of intergranular limemud [29]. The presence of fully cement matrix, lack of limemud and size of the grains forming these microfacies indicate the high level of energy during the formation of this microfacies in a shoal environment [30]-[32]. The presence of stenohalins like crinoid and brachiopod in microfacies $\mathrm{C}_{1}, \mathrm{C}_{2}$ and $\mathrm{C}_{4}$ points to association of these microfacies with open marine [33]. In microfacies $C_{2}$ the presence of intraclast, coated grains and good sorting is a sign of shoal environment [11]. Skeletal fragments like bryozoan, relating to shoal environment can also be seen in $\mathrm{C}_{3}$ microfacies [8] [21] [34]. This environment causes a separation between lagoon and open marine environments. The presence of grainstone and good sorting as well as lack of limemud in these microfacies imply the high level of energy there [19]. Lack of micrite is the major cause of high level of energy in these microfacies. Large size of grains and their relative sorting are among other factors determining the high level of energy in these microfacies. In microfacies $C_{5}$, major skeletal components, especially benthic foraminifera and pellet can be found in a micritic and sparite matrix. This microfacies is situated in leeward shoal [8].

\subsection{Facies Belt}

D: open marine environment

This facies belt is composed of only one microfacies as follow:

$\mathrm{D}_{1}$ : Crinoid Wackestone microfacies

This microfacies includes 20\% 1-mm sized crinoid, located in a micritic matrix. Crinoid fracture in this microfacies suggests carrying from shoal towards open marine environment (Figure 8).

\section{Interpretation}

The intergranular muddy matrix [35] points to the formation of depositsin a low-energy and calm environment like open marine. Regarding the abundance of stenohalins like crinoid, this microfacies is formed in a normal saline environment like open marine [11] [23] [36].

\section{Depositional Environment Model of Sartakht Formation in Bakhshi Section}

According to the microscopic and field observations, vertical relationship between microfacies and the comparison made between microfacies of Sartakht formation and current depositional microfacies, the depositional model of Sartakht formation in Bakhshi section is presented in Figure 9. This model represents the position of the formation of siliciclastic petrofacies and carbonate microfacies of the mentioned facies in tidal flat, lagoon,

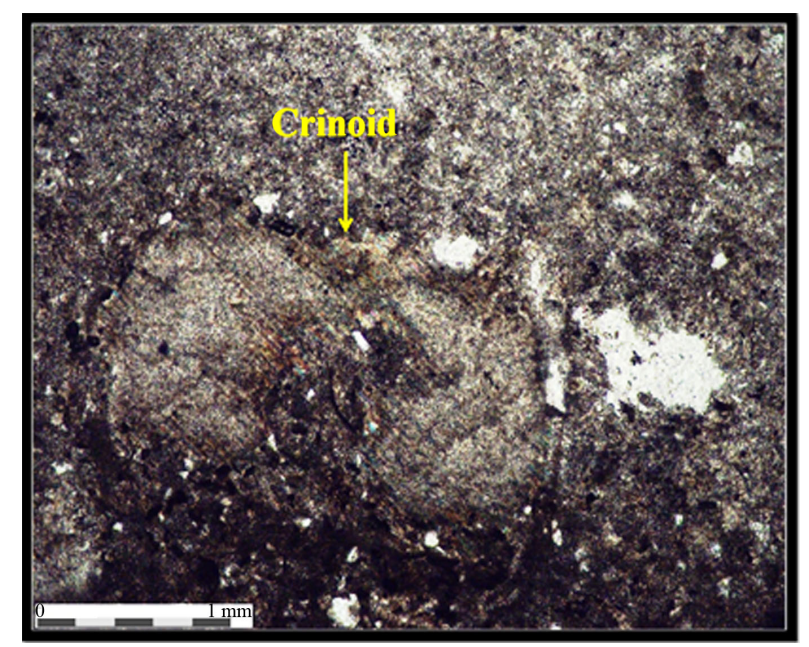

Figure 8. Carbonate microfacies of open marine environment of Sartakht formation in Bakhshi section: Crinoid Wackestone. $1 \mathrm{~mm}$ scale. 


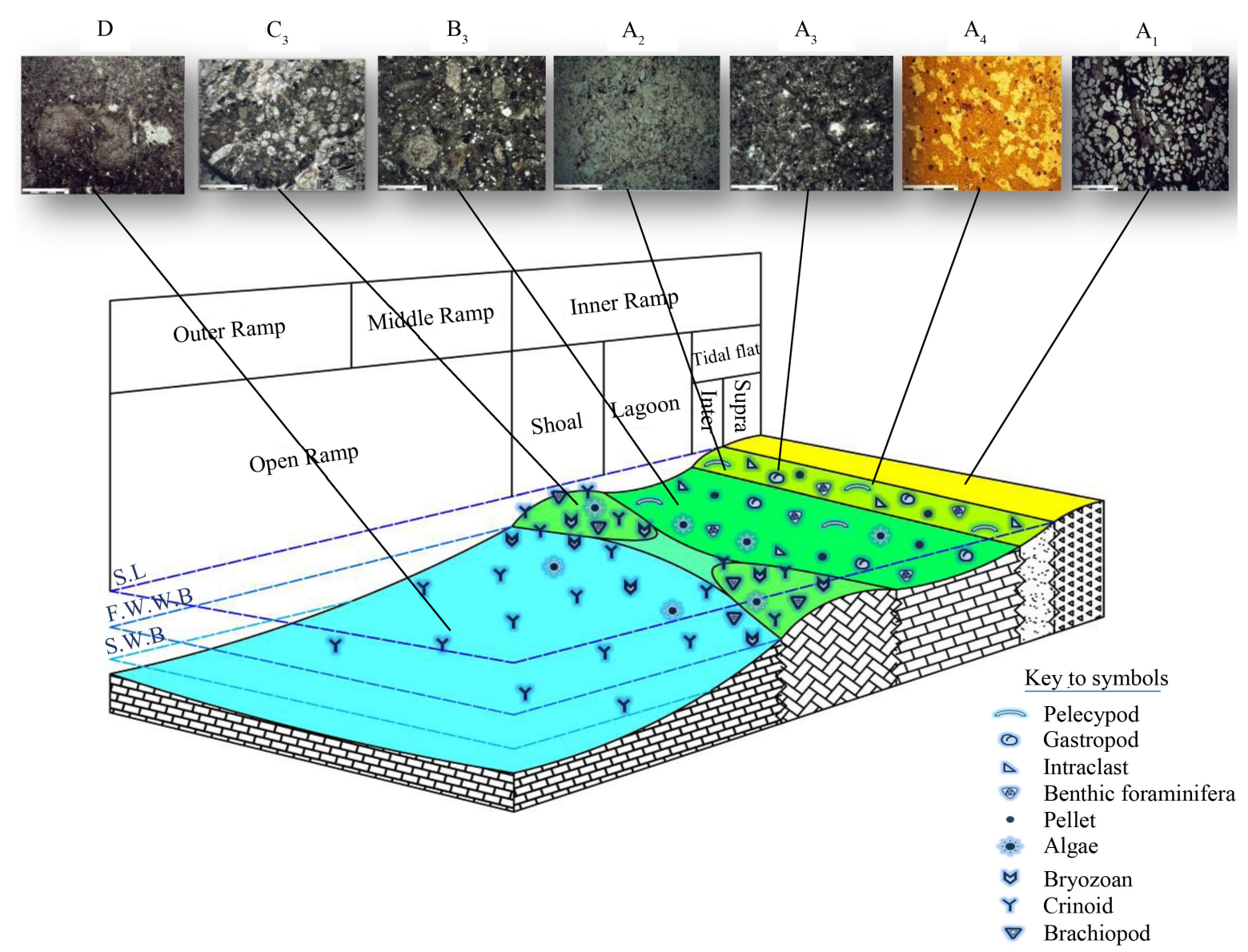

Figure 9. Depositional environment model of Sartakht formation in Bakhshi section.

shoal and open marine environments. Owning to the lack of calciturbidite, slumps, barrier reefs and oncolite as well as presence of gradual facies, this petrofacies and its microfacies are formed in a low-angle homoclinal carbonate-siliciclastic ramp [15] [24] [37], located in the passive margin in south of Paleotethys Ocean [38]. Investigating the microfacies and depositional environment of Sartakht environment in Bakhshi section indicate that shallow marine environment is observed in Middle Permian, where various microfacies of Sartakht formation are deposited. As can be seen in the proposed model, oxidized sublitharenite petrofaciesis deposited in an oxidized supratidal subenvironment, pointing to their formation in a warm and humid climate. Quartzarenite petrofacies of siliciclastic facies is associated with lower intertidal, indicating the relatively high energy in this environment. Mature quartzarenite petrofacies, moreover, confirms upper flow tidal regimes. Fenestral and Bird'seye fabrics are common in upper intertidal microfacies. Deposits of lagoon environment are laid in a restricted to semi-restricted environment, separated from shoal environment by organisms like bryozoan contributing to the formation of shoal environment. Open marine environment is characterized by the presence of crinoid fragments in a limemud matrix and its thickness is less than other environments.

\section{The Frequency Column of Microscopic Microfacies}

These microscopic microfacies consist of orthochem and allochem components, the type of matrix or cement and the type of skeletal and non-skeletal. The frequency percentage of allochem is computed by polarizan microscope and depicted separately for each allochem. It is noteworthy that only two samples of units $1 \& 2$ are studied due to their lateritic and nonremovable nature (Figure 10).

\section{Sequence Stratigraphy of Sartakht Formation in Bakhshi Section}

Sequence stratigraphy is a method of classifying and interpreting sedimentary rocks and fossils in terms of 
variations in the environments [39]. The variation in the weather and sea level can be detected through careful analysis of sequence stratigraphy [40]. According to the literature and various sections of Sartakht formation in Bakhshi section, Kalmard block, a third order, siliciclastic-carbonate depositional sequence, belonging to Middle Permian is identified. All and all, the source of sediment supply is the first factor causing distinction between carbonate and siliciclastic systems [41].

\section{Depositional Sequence of Sartakht Formation in Bakhshi Section}

As a siliciclastic-carbonate sequence, 58.6 m-thick depositional sequence is underlain by Chili formation and

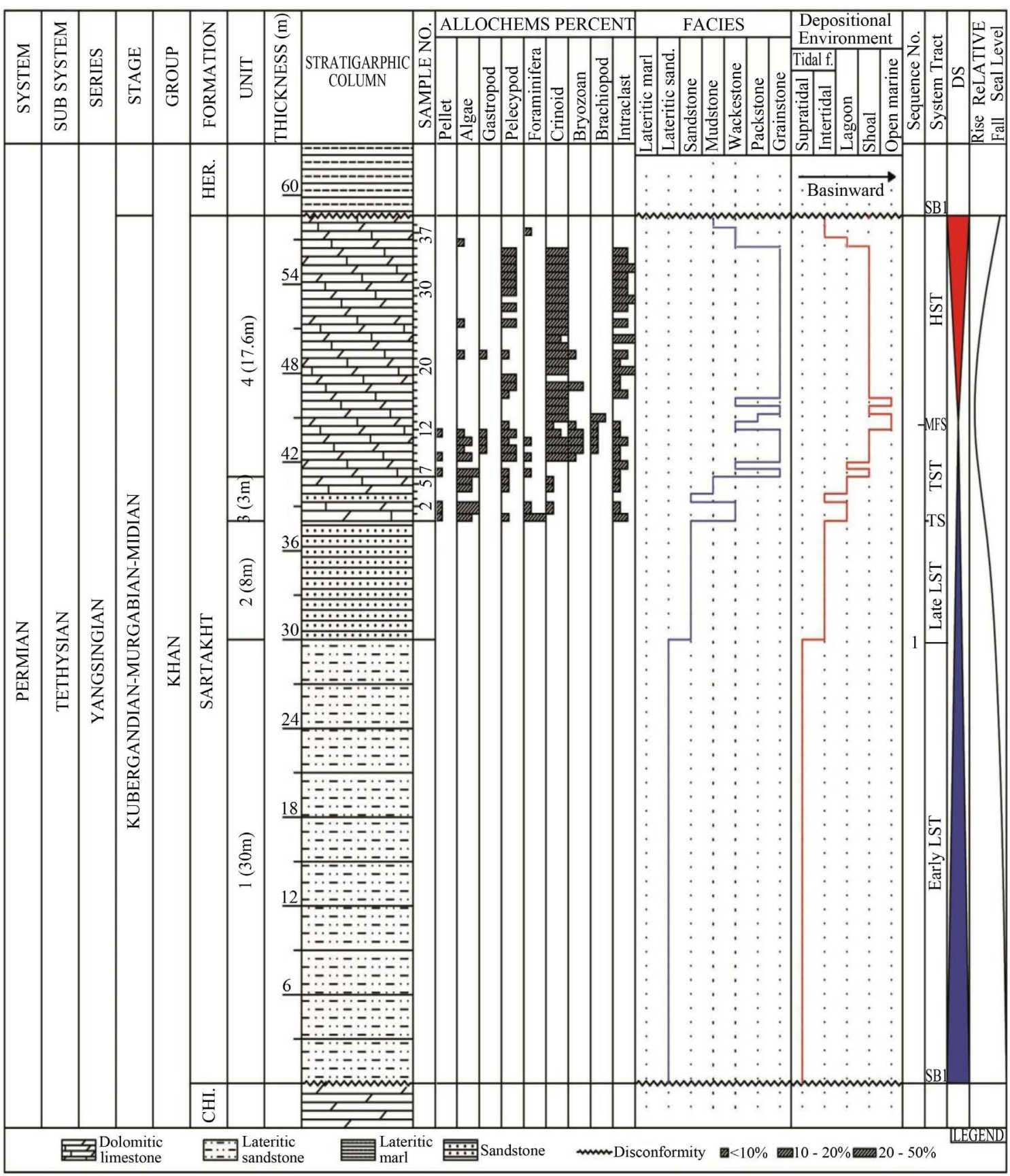

Figure 10. Frequency column of microscopic microfacies and depositional sequence of Sartakht formation in Bakhshi section. 
overlain by Hermez formation. In this sequence, LST system tract unconformably overlies chili formation. This is a kind of erosional unconformity located between medium, yellow, dolomites of Chili formation and oxidized and lateritic sandstones of Sartakht formation in Bakhshi section. This LST system tract consists of early LST and late LST. Early LST contains thin-to-medium, red, oxidized lateritic sandstones, indicating moving out of water and weathering. These sandstones include oxidized sublitharenite petrofacies and belong to tidal flat environment (Supratidal subenvironment). This siliciclastic petrofacies is deposited in oxidation conditions, pointing to its formation in a warm and humid climate. Finally, these weathered and oxidized sandstones end to tidal flat microfacies (Intertidal subenvironment), relating to Late LST (Figure 10). Late LST is composed of medium, horizontally stratified sandstones, enjoying quartzarenite petrofacies with progradational stacking pattern. It is possible for this system tract to be formed during a sea level fall. LST system track is $38 \mathrm{~m}$ thick in the desert. Overlying LST system tract, TST is identified by layers of dolomitic limestone, interbedded by sandstone and lagoon microfacies (Sandy Dasycladacea Wackestone).

TST system tract, showing deepening trend with retrogradational stacking pattern, consists of carbonate parasequences, tidal flat microfacies (Quartzarenite), lagoon microfacies (Sandy Dasycladacea Wackestone, Dolomitized Sandy Bioclast Dasycladacea Crinoid Packstone, Bioturbated Dolomitized Sandy Intraclast Algal Bioclast Packstone, Sandy Intraclast Algal Packstone), shoal microfacies (Sandy Algal Intraclast Pelecypoda Crinoid Grainstone, Bioclast Bryozoan Grainstone, Bioclast Algal Packstone/Grainstone) and open marine microfacies (Crinoid Wackestone).

This system tract is observable in the desert in terms of medium, gray, horizontally stratified dolomitic limestone, interbedded with layers of $6.6 \mathrm{~m}$-sized, thin to medium, reddish sandstone. This system tract is progradationally followed by maximum flooding surface (MFS), identified by open marine, crinoids wackestone microfacies. This surface, preceded by TST system tract, is characterized by thin-to-medium, light gray, horizontally stratified dolomitic limestone.

HST system tract, exhibiting a shallowing trend with progradational stacking pattern, contains open marine, shoal, lagoon and tidal flat microfacies. This system tract, overlain by abundant crinoid, is characterized bythinto-medium, light gray, horizontally stratified dolomitic limestone, consisting of open marine microfacies (Crinoid Wackestone), shoal microfacies (Dolomitized Sandy Brachiopod Algal Crinoid Grainstoneand Brachiopod Crinoid Grainstone), lagoon microfacies (Sandy Dasycladacea Wackestone) and tidal flat microfacies (Intertidal subenvironment) (Fenestral Sandy Bioclast Wackestone and Dolomitized Fenestral Mudstone). This system tract is $14 \mathrm{~m}$ thick. This sequence ends finally in SB1, made up of eroded, thin-to-medium, dark red, lateritic paleosol. This paleosols belong to Hermez formation, unconformably overlying Sartakht formation in Bakhshi section (Figure 11).

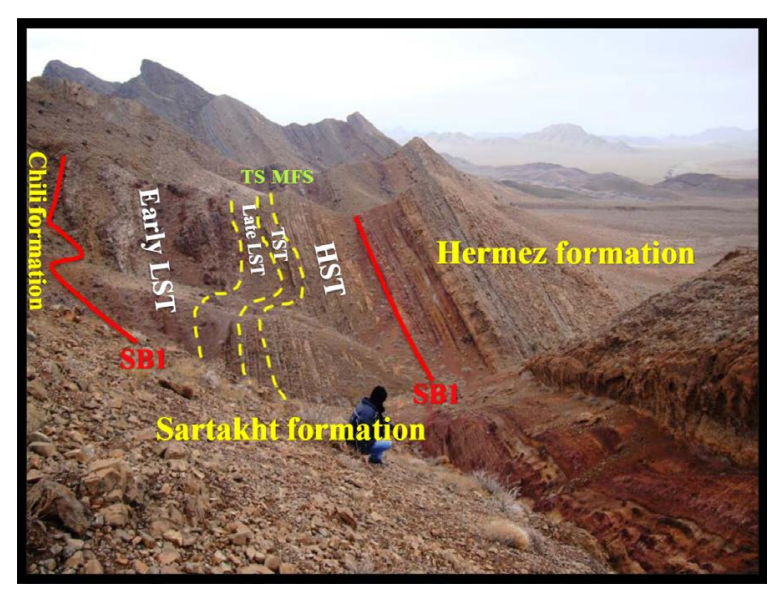

Figure 11. Image of depositional sequence of Sartakht formation in Bakhshi section: Early LST contains thin-to-medium, red, oxidized lateritic sandstones and belongs to supratidal flat environment. Late LST is composed of medium, horizontally stratified sandstones and belongs to intertidal flat environment. TS surface is characterized by layers of dolomitic limestone. TST system tract, showing deepening trend with retrogradational stacking pattern, consists of carbonate parasequences, tidal flat microfacies (intertidal subenvironment), lagoon microfacies, shoal microfacies and open marine microfacies. MFS contains thin-to-medium, light gray, horizontally stratified dolomitic limestone and is identified by open marine, Crinoid Wackestone microfacies. HST, overlain by abundant crinoid, is characterized by thin-to-medium, light gray, horizontally stratified dolomitic limestone. 


\section{Interpretation of the Depositional Sequence Identified in Sartakht Formation in Bakhshi Section}

According to microscopic investigations, field observations and sequence stratigraphy, Sartakht formation involves a third order depositional sequence and a lot of high frequency cycle. This sequence is equivalent to upper parts of subordinate large-scale Absaroka II [42] and is identical to proposed sequences in other parts of the world (asterisk in Figure 12). The lower boundary of the depositional sequence of Sartakht formationin Bakhshi section is a type 1 unconformity, overlying the carbonate deposits of Chili formation. These deposits are composed of sandstone and dolomitic limestone, and its MFS is identified by open marine, crionid wackestone microfacies. In Kalmard siliciclastic-carbonate platform, the sedimentary basin reacts more apparently against sealevel fluctuation due to its shallowness. The sandstone at the beginning of the sequence confirms this claim and points to the rapid change in the conditions. Therefore, one can claim that relative sea level fall leads to the formation of SB1 between Chili and Sartakht formations. MFS is usually identified by the presence of crinoids, which in turn are recognized by crinoid wackestone microfacies. One of the consequences of LST system tract

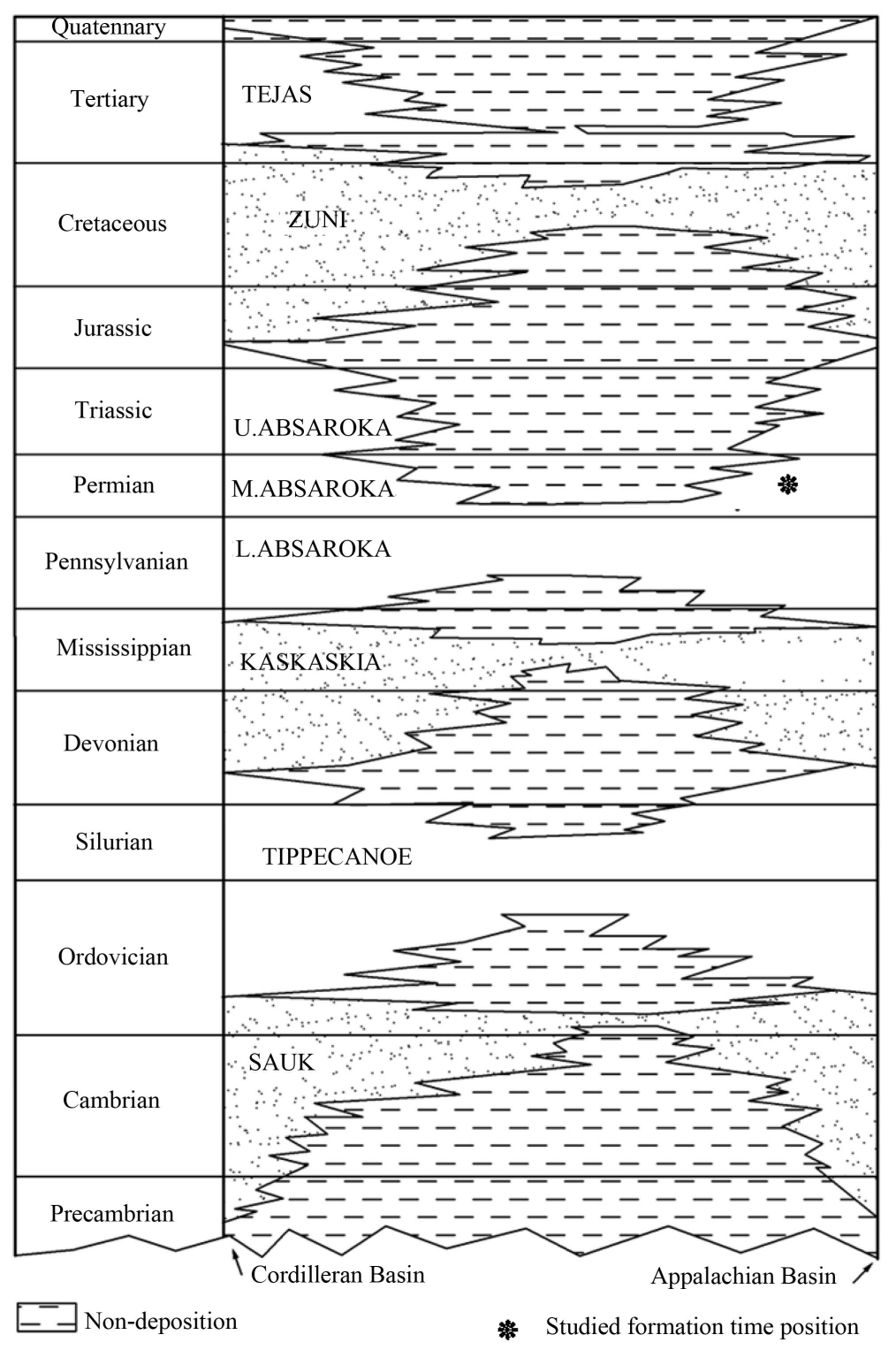

Figure 12. Location of Sartakht formation in Bakhshi section and global-scale subsequences are marked by asterisk (Sloss, 1963). 
in siliciclastic-carbonate systems is the expansion of siliciclastic depositions. Once sea level is lower than the edge of the continental shelf, more siliciclastic materials enter the environment [43]. Regarding the evidence, the sequence model of this formation suggests once the sea water moves forward, carbonate deposits of lagoon, shoal and open marine microfacies overlies the sandstone deposits of tidal flat environment. The rate of sea level fall exceeds the rate of tectonic subsidence in SB1, causing the depositional environment to move out of water.

\section{Conclusions}

Having analyzed the facies, depositional environment and sequence stratigraphy of the deposits of Khan Group (Sartakht formation) in Bakhshi section, the researchers came up with the following results:

Middle Permian rocks (Kubergandian, Murgabian and Midian stages) are deposited in Kalmard block in informal Sartakht formation and consist of sandstone, limestone and dolomitic limestone. One of the most comprehensive outcrops of Sartakht formation is situated in Bakhshi section and is $58.6 \mathrm{~m}$ thick. According to the carbonate composition of the rocks in this formation, accompanied by considerable siliciclastic deposits (sandstone of unite $1 \& 2$ ), deposits of this formation are formed in warm and humid climate and close to the siliciclastic deposits supply. Investigating the lithofacies of the depositis of sartakht formation in Bakhshi section resulted in identifying 2 siliciclastic petrofacies and 12 carbonate microfacies. Regarding microscopic and field observations, siliciclastic petrofacies and carbonate microfacies of this section, facing sea from the coast, include: tidal flat environment, lagoon environment, shoal environment and open marine environment. The vertical and lateral changes of microfacies and comparing them with late and early depositional environments indicate that lack of calciturbidite deposits, slumps, barrier reef and oncolite and presence of gradual facies have caused the mentioned deposits to be formed in a low-angle homoclinal ramp, mostly in the inner ramp, located in the passive margin in south of Paleotethys Ocean. According to the microscopic investigations, field observations and sequence stratigraphy, Sartakht formation contains a third order depositional sequence and a lot of high frequency cycle. This sequence is equivalent to upper parts of Middle Absaroka II super sequence and identical to the proposed sequences for other parts of the world. The lower boundary of the depositional sequence of Sartakht formation in Bakhshi section unconformably overlies carbonate deposits of Chili formation and is made up of thin-to-medium, reddish, oxidized and lateritic sandstone. The deposits of this sequence consist of sandstone and dolomitic limestone and its MFS is identified by open marine, crinoid wackestone microfacies. In this sequence, likely sea level fall is the result of global-scale glacial and local tectonic activities (subsidence of basin floor and vertical movement of the existing faults). It is noteworthy that the studied area showed no glacial activities like dropstone, Striation and Diamictite, yet the global sequences are formed as a result of sea level fall on a global scale.

\section{References}

[1] Aghanabati, A. (2004) Geology of Iran. Geological Survey of Iran, Tehran, 606 p.

[2] Aghanabati, A. (1977) Etudgeologique de la region de Kalmard (W. Tabas). Geological Survey of Iran, No. 35, 51-63.

[3] Azhdari, A. (1999) Geological Map and Report of Robat-e-Khan, on Scale of 1:100,000. Geological Survey of Iran. Tehran.

[4] Dickson, J. (1965) A Modified Staining Technique for Carbonate in Thin Section. Nature, 205, 587.

[5] Folk, R.L. (1974) Petrology of Sedimentary Rocks. Hemphill Publishing Company, Austin, 182 p.

[6] Dunham, R.J. (1962) Classification of Carbonate Rocks According to Depositional Texture. In: Ham, W.E., Ed., Classification of Carbonate Rocks, a Symposium, AAPG Mem., No. 1, 108-121.

[7] Embry, A.F. and Klovan, J.E. (1971) A Late Devonian Reef Tract on Northeasterm Banks Island. Canadian Petroleum Geology, 19, 730-781.

[8] Wilson, J.L. (1975) Carbonate Facies in Geologic History. Springer, New York, 471 p. http://dx.doi.org/10.1007/978-1-4612-6383-8

[9] Carozzi, A.V. (1989) Carbonate Rocks Depositional Model. Prentice Hall, Upper Saddle River, 604 p.

[10] Tucker, M.E. and Wright, V.P. (1990) Carbonate Sedimentology. Blackwell Scientific Publication, Palo Alto, 496 p. http://dx.doi.org/10.1002/9781444314175

[11] Flügel, E. (2010) Microfacies of Carbonate Rocks, Analysis, Interpretation and Application. Springer-Verlag, Berlin, $996 \mathrm{p}$. 
[12] Posamentier, H.M., Jervey, M.T. and Vail, P.R. (1988) Eustatic Controls on Clastics Deposition I-Conceptual Framework. In: Wilgus, C.K., Hasting, B.H., Kendall, C.G.ST.C., Posamentier, H.W., Ross, C.A. and Van Wagoner, J.C., Eds., Sea Level Changes: An Integrated Approach, SEPM, Special Publication, No. 420, 109-124. http://dx.doi.org/10.2110/pec.88.01.0109

[13] Bardossy, G. (1982) Karst Bauxites, Bauxite Deposits on Carbonate Rocks, Developments in Economic Geology, Elsevier, Amsterdam, Vol. 14, 441 p.

[14] Ozlo, N. (1983) Trace-Element Content Karst Bauxites and Their Parent Rock in the Mediterranean Belt. Mineralumdeposita, 18, 469-476.

[15] Read, J.F. (1985) Carbonate Platform Facies Models. AAPG Bulletin, 69, 1-21.

[16] Pettijohn, F.J., Siever, R. and Potter, P.E. (1987) Sand and Sandstone. 2nd Edition, Springer-Verlag, Berlin, 553 p. http://dx.doi.org/10.1007/978-1-4612-1066-5

[17] Khalifa, M.A., Soliman, H.E. and Wanas, H.A. (2006) The Cambrian Araba Formation in Northeastern Egypt: Facies and Depositional Environments. Journal of Asian Earth Sciences, 27, 873-884. http://dx.doi.org/10.1016/j.jseaes.2005.09.003

[18] Shinn, A. (1983) Tidal Flat Environment. In: Schlle, A., Debout, D.G. and Moore, C.H., Eds., Carbonate Depositional Environment, AAPG Memoir, Vol. 33, 173-210.

[19] Adabi, M.H., Salehi, M.A. and Ghabeishavi, A. (2010) Depositional Environment, Sequence Stratigraphy and Geochemistry of Lower Cretaceous Carbonates (Fahliyan Formation), South-West Iran. Journal of Asian Earth Sciences, 39, 148-160. http://dx.doi.org/10.1016/j.jseaes.2010.03.011

[20] Adabi, M.H., Kakemem, U. and Sadeghi, A. (2015) Sedimentary Facies, Depositional Environment, and Sequence Stratigraphy of Oligocene-Miocene Shallow Water Carbonate from the Rig Mountain, Zagros Basin, (SW Iran). Carbonates and Evaporites, 31, 5-8.

[21] Adabi, M.H. and Asadi Mehmandosti, E. (2008) Microfacies and Geochemistry of the Ilam Formation in the Tang-E Rashid Area, Izeh, SW Iran. Journal of Asian Earth Sciences, 33, 267-277. http://dx.doi.org/10.1016/j.jseaes.2008.01.002

[22] AsadiMehmandosti, E., Adabi, M.H. and Wood, D. (2013) Microfacies and Geochemistry of the Middle Cretaceous Sarvak Formation in the Zagros Basin, Izeh Zone, SW Iran. Sedimentary Geology, 293, 9-20. http://dx.doi.org/10.1016/j.sedgeo.2013.04.005

[23] Amalain, M. and Adabi, M.H. (2015) Geochemistry, Microfacies and Diagenetic Evidences for Original Aragonite Mineralogy and Open Diagenetic System of Lower Cretaceous Carbonates Fahliyan Formation (Kuh-Esiah) Area, Zagros Basin, South Iran. Carbonates and Evaporites, 30, 77-98. http://dx.doi.org/10.1007/s13146-014-0211-8

[24] Brandano, M., Frezza, V., Tomassetti, L., Matteucci, R. and Pedley, M. (2010) Facies Analysis and Paleoenvironmental Interpretation of the Late Oligocene Attard Member (Lower Coralline Limstone Formation), Malta. Sedimentology, 56, 1138-1158. http://dx.doi.org/10.1111/j.1365-3091.2008.01023.x

[25] Boudagher-Fadel, M.K. and Lokier, S.W. (2005) Significant Miocene Larger Foraminifera from South Central Java. Revue de Paleobiologie, Geneve, 24, 291-309.

[26] Basso, D., Nalin, R. and Nelson, C.S. (2009) Shallow-Water Sporolithon Rhodoliths from North Island (New Zealand). Palaios, 24, 92-103. http://dx.doi.org/10.2110/palo.2008.p08-048r

[27] Nebelsick, J.H., Rasser, D. and Lempp, J. (2012) Tracking Paleoenvironmental Changes in Coralline Algal-Dominated Carbonates of the Lower Oligocene Calcareniti di Castelgomberto Formation (Monti Berici, Italy). Facies, 59, 133148. http://dx.doi.org/10.1007/s10347-012-0349-6

[28] Adabi, M.H. and Rao, C.P. (1996) Petrographic, Elemental and Isotopic Criteria for the Recognition of Carbonate Mineralogy and Climates during the Jurassic (Examples from Iran and England). 13th Australia Geological Convention, (abst), Canberra, 19-23 February 1996, 6.

[29] Ahmad, A.H.M., Bhat, G.M. and Haris Azim Khan, M. (2006) Depositional Environments and Diagenesis of the Kuldhar and Keera Dome Carbonates (Late Bathonian-Early Callovian) of Western India. Journal of Asian Earth Sciences, 27, 765-778. http://dx.doi.org/10.1016/j.jseaes.2005.06.013

[30] Betzler, C., Braga, J.C., Martin, J.M., Sanchez-Almazo, I.M. and Lindhorst, S. (2006) Closure of a Seaway: Stratigraphic Record and Facies (Guadix Basin, Southern Spain). International Journal of Earth Sciences, 95, 903-910. http://dx.doi.org/10.1007/s00531-006-0073-y

[31] Palma, R.M., Lopez Gomez, J. and Piethe, R.D. (2007) Oxfordian Ramp System (La Manga Formation) in the Bardas Area (Mendoza Province) Neuquen Basin, Argantina: Facies and Depositional Sequence. Sedimentary Geology, 195, 113-134. http://dx.doi.org/10.1016/j.sedgeo.2006.07.001

[32] Khatibi, M. and Adabi, M.H. (2013) Microfacies and Geochemical Evidence for Original Aragonite Mineralogy of a Forminifera-Dominated Carbonate Ramp System in the Late Paleocene to Middle Eocene, Alborz Basin, Iran. Carbonates and Evaporites, 29, 155-175. http://dx.doi.org/10.1007/s13146-013-0163-4 
[33] Heckel, H. (1972) Recognition of Ancient Shallow Marine Environment, In: Rigby, J.K. and Hemblin, K., Eds., Recognition Ancient Sedimentary Environments, Vol. 161, SEPM Special Publication, Tulsa, 226-286. http://dx.doi.org/10.2110/pec.72.02.0226

[34] Amir-shahkarami, M., Vaziri-Moghaddam, H. and Taheri, A. (2007) Sedimentary Facies and Sequence Stratigraphy of the Asmari Formation at Chaman-Bolbol, Zagros Basin, Iran. Journal of Asian Earth Sciences, 29, 947-959. http://dx.doi.org/10.1016/j.jseaes.2006.06.008

[35] Adachi, N., Ezaki, Y. and Liu, J. (2004) The Origin of Peloids Immediately after the End Permian Extinction, Guizhou Province, South China. Sedimentary Geology, 146, 161-178. http://dx.doi.org/10.1016/j.sedgeo.2003.10.007

[36] Bachmann, M. and Hirisch, F. (2006) Lower Cretaceous Carbonate Platform of the Eastern Levant (Galilee and the Golan Heights): Stratigraphy and Second-Order Sea-Level Change. Cretaceous Research, 27, 487-512. http://dx.doi.org/10.1016/j.cretres.2005.09.003

[37] Tucker, M.E. (2008) Sedimentary Petrology. 3rd Edition, Blackwell Publishing, Oxford, 262 p.

[38] Berberian, M. and King, G.C.P. (1981) Toward a Paleogeography and Tectonic Evolution of Iran. In: Berberian, M., Ed., Continental Deformation in the Iranian Plateau, Report, No. 52, Geological Survey of Iran, Tehran, Report No. 52, 502-530. http://dx.doi.org/10.1139/e81-019

[39] Naish, T.R., Abbott, S.T. and Carter, R.M. (2013) Sequence Stratigraphy Reference Module in Earth Systems and Environmental Sciences. In: Elias, S.A., Ed., Encyclopedia of Quaternary Science, 2nd Edition, Elsevier, Amsterdam, 260-276. http://dx.doi.org/10.1016/B978-0-444-53643-3.00066-2

[40] Patricio, R.D., Luis, A.B., Carlos, O.L. and Gabriela, A.C. (2009) Latest Carboniferous-Earliest Permian Transgressive Deposits in the Paganzo Basin of Western Argantina: Lithofacies and Sequence Stratigraphy of a Coastal Plain to Bay Succession. Journal of South American Earth Sciences, 28, 40-53. http://dx.doi.org/10.1016/j.jsames.2008.10.003

[41] Schlager, W. (2005) Carbonate Sedimentology and Sequence Stratigraphy. Vol. 8, SEPM Concepts in Sedimentology and Paleontology. 200 p. http://dx.doi.org/10.2110/csp.05.08

[42] Sloss, L.L. (1963) Sequence in Cratonic Interior of North America. Geological Society of America Bulletin, 74, 93114. http://dx.doi.org/10.1130/0016-7606(1963)74[93:SITCIO]2.0.CO;2

[43] Alonso-Zarza, A.M. and Tanner, L.H. (2010) Carbonates in Continental Setting: Facies, Environments and Processes, Developments in Sedimentology. Elsevier, Amsterdam, 225-267. 